\title{
Taxes and Death: The Rise and Demise of an American Law Firm
}

Milton C. Regan

Georgetown University Law Center, regan@law.georgetown.edu

Georgetown Business, Economics and Regulatory Law Research Paper No. 11-08

This paper can be downloaded free of charge from:

https://scholarship.law.georgetown.edu/facpub/625

http://ssrn.com/abstract=1802697

52 Studies in Law, Politics and Society: Law Firms, Legal Culture, and Legal Practice 107-144 (Austin Sarat ed., Greenwich, Conn.: JAI Press 2010)

This open-access article is brought to you by the Georgetown Law Library. Posted with permission of the author. Follow this and additional works at: https://scholarship.law.georgetown.edu/facpub

Part of the Legal Profession Commons, and the Tax Law Commons 


\title{
Taxes and Death: \\ The Rise and Demise of an American Law Firm
}

\author{
Milton C. Regan, Jr. \\ Georgetown University Law Center
}

This paper is a chapter in the volume Law Firms, Legal Culture, and Legal Practice, a special issue of STUDIES IN LAW, POLITICS, AND SOCIETY, Vol. 52, pp. 107-144 (Austin Sarat ed. 2010):

http://books.emeraldinsight.com/results.asp?sf1=series\&st1=Studies\%20in\%2 0Law,\%20Politics\%20\&\%20Society\&sort=sort date/d\&CUR=GBP 


\section{Taxes and Death: The Rise and Demise of an American Law Firm Milton C. Regan, Jr.}

\section{Introduction: The End of a Law Firm}

On March 31, 2007, the national law firm of Jenkens \& Gilchrist closed its doors because of wrongdoing by three of its partners. Two days before, the firm had acknowledged liability of $\$ 76$ million to the Internal Revenue Service (IRS) for its lawyers' promotion of abusive and fraudulent tax shelters. (Internal Revenue Service 2007). That same day, the Department of Justice announced that it had agreed not to prosecute Jenkens \& Gilchrist, based on representations that the firm would shortly cease operations and that its representatives would cooperate with the criminal investigation of tax shelter work at the firm. (U.S. Department of Justice 2007). Thus ended the life of the fastest growing law firm in the United States less than a decade before, and a pillar of the Dallas corporate establishment for over half a century.

Jenkens \& Gilchrist's press release in connection with the non-prosecution agreement said that certain of its lawyers "developed and marketed fraudulent tax shelters," and that Jenkens "failed to exercise effective oversight and control over the firm's tax shelter practice." (Jenkens \& Gilchrist 2007). On June 9, 2009, Paul Daugerdas and two other partners in the Chicago office, Erwin Mayer and Donna Guerin, were indicted for their work on tax shelters. (Indictment 2009).

For some, the story of Jenkens \& Gilchrist is simple: it's another example of how business considerations have led law firms in recent years to neglect their professional duties. Both journalists and scholars have written extensively about intensified competition in the legal services market over the last quarter century. (Hansen 1995; Galanter \& Henderson 2008; Galanter \& Palay 1991; Koppel 2007; Regan 2004; Triedman 2007). Observers suggest that this 
trend has produced especially profound changes in law firms. Compensation, tenure, promotion, growth, governance, and training are but a few of the dimensions of law firm practice whose transformation has been attributed to the flood of market forces into former competitive backwaters. (Galanter \& Henderson 2008; Galanter \& Palay 1991; Regan 2004).

An important theme in recent literature on legal ethics is that greater law firm emphasis on business considerations has weakened lawyers' commitment to ethical behavior. (Linowitz 1994). One critique is that law firms now give more weight to their own financial interest at the expense of clients. This leads them to do things like ignore conflicts of interest, pad their bills, and eschew opportunities to provide more efficient services for their clients.

A related story of declining ethics in law firm practice is that firms are less willing to take into account the impact of client activities on third parties because they don't want to jeopardize their relationships with clients. Companies who face fierce competitive pressures want lawyers who can help them achieve their objectives, not ones who point out the impacts that doing so will have on third parties. They want litigators who will press for every advantage and counselors who will exploit every regulatory loophole, not lawyers who feel bound by nebulous duties that supposedly arise from being an officer of the court.

There is no question that competition is now a major influence in law firm decision making, nor that both lawyers and law firms face substantial insecurity. Any account of behavior in law firms must take this into account. Broad pronouncements of simple cause and effect based on business pressure have limited explanatory power, however.

First, such explanations treat the legal services market as an undifferentiated force that exerts the same type of pressure on all law firms. The market tends to be depicted as a 
monolithic engine that pushes firms in every case to choose the most profitable course of action. In any given situation, a firm may give in to or resist this pressure, but it cannot escape it.

This story, however, doesn't describe in much detail the sources of these competitive pressures, the particular forms that the pressures take in daily practice, the business strategies that firms develop to respond to them, or what characteristics can give firms an edge or leave them at a disadvantage in dealing with competition. It ignores the increasing consolidation and segmentation of the legal services market, and the ways in which different firms and practice areas can face distinctive competitive dynamics. It also neglects the fact that firms may adopt various formal and informal safeguards to respond to the risks of misconduct posed by intensified market pressures. (Chambliss \& Wilkins 2002)

The failure to take such refinements into account can leave us ill-equipped to understand how firms may operate under different competitive conditions, adopt different business strategies, confront particular ethical issues, and generate contrasting -- and sometimes internally inconsistent -- organizational cultures. Saying that market forces shape law firm behavior thus is useful as far as it goes, but it doesn't go very far. As I will suggest, we can gain a richer understanding of the events surrounding Jenkens \& Gilchrist if we appreciate the particular market segment in which it operated, the specific concerns that led to the firm's business strategy, and how Paul Daugerdas' tax shelter practice offered an especially attractive opportunity to further the firm's ambitions.

A second tendency in discussion of business pressures on law firms is to treat the firm as the individual writ large, which reacts more or less in direct fashion to market pressures. This assumes that law firm behavior is the product of a systematic assessment of various alternatives. Organization theory cautions us against treating entities in casual anthropomorphic fashion. 
Behavior is often the result of a complex mix of formal and informal influence. Furthermore, people in organizations exhibit common psychological tendencies that can depart significantly from strict rationality. (Darley, et al. 2001; Messick \& Tenbrunsel 1997)

We should be especially wary of assuming that law firm managers wield power in a relatively direct system of command and control. Lawyers, for instance, typically have a strong desire for independence. Coordinating their activity thus can be extraordinarily difficult. Unlike in the typical business organization, law firm leaders derive little authority from their positions alone. They usually are unable to influence behavior by issuing edicts from on high. In addition, the relative ease of moving from one firm to another can give profitable lawyers an effective veto over managerial initiatives. Law firm managers therefore must rely mainly on negotiation and persuasion to gain the cooperation of others. As I discuss below, the process of hiring Paul Daugerdas was a complex one in which a number of lawyers participated and expressed a variety of opinions. These deliberations did not necessarily reflect a disinterested assessment of prospective risks and rewards. Furthermore, hiring him created a situation in which both inertia and profits would pose obstacles to subjecting Daugerdas' activity to effective ongoing scrutiny.

A more refined appreciation of the legal services market and of law firm dynamics can help illuminate the particular types of pressures that leaders in a given firm may confront. It also directs attention to the ways in which certain choices that seem unproblematic may set in motion a series of other likely choices that increase the risk of misconduct. This underscores that ethics in the modern law firm requires more than just choosing the correct fork in the road when time comes. It also demands remaining alert to where one may be headed each step along the way. This requires that we appreciate the cognitive and moral universes that law firm lawyers inhabit as they go about their work. 
Appreciating trends in the legal services market and the distinctive systems of influence and power in law firms can help illuminate those universes. It offers a chance to work on an intermediate level of analysis between a focus on broad market forces on the one hand and the unique details of individual law firms on the other. This can enable us to identify how firms can be both similar to and different from each other. Analyzing behavior from this perspective may yield more nuanced insights into some of the wellsprings of behavior in modern law firms.

Below, I apply these ideas to the events surrounding Jenkens \& Gilchrist. On one level, Jenkens represents the story of a law firm that couldn't resist the chance to boost its profits by hiring a lawyer the firm should have known was ignoring his professional responsibilities. This description contains some truth. It paints with a broad brush, however, lumping Jenkens together with all other law firms without offering much detail about how human choices and environmental pressures combined to bring down the firm. The result is that the events surrounding Jenkens would seem to offer few lessons other than to choose right over wrong.

I believe that we can gain greater insight by looking more closely at the market segment in which Jenkens \& Gilchrist operated, how its business strategy represented a response to conditions in that market, the people and events that enabled the firm to pursue that strategy, how tax shelter work offered an especially good fit with Jenkens' ambitions, and the trade-offs that the firm made in inviting Paul Daugerdas to join it. In turn, we need to examine how these forces were refracted through the perspectives and interests of various people in the firm, and the ways in which decision makers could conclude that the firm was making a rational decision.

Part I of what follows describes the main features of the market for law firm services. Part II discusses the ways in which individual psychological tendencies interact with organizational characteristics to shape perceptions of risk and provide rationalizations for 
behavior. Part III tells the story of Jenkens \& Gilchrist from its founding until Paul Daugerdas approached it with a proposal to join the firm. Part IV examines the deliberations within the firm about whether to accept Daugerdas' offer, and describes the work that Daugerdas did once he joined the firm.

The next two Parts apply the analytical framework laid out in Parts I and II to the rise and fall of Jenkens \& Gilchrist. Part IV illuminates why Daugerdas' practice was especially attractive to Jenkens in light of the competitive pressures that the firm faced and the business strategy that it had adopted. Part V explores how behavioral patterns in organizational settings may have led decisionmakers to rationalize that Daugerdas posed predictable risks that the firm was capable of managing. Finally, the Conclusion suggests that the Jenkens \& Gilchrist story illustrates that the analytical approach that I have employed can be enriched especially by further research on the elements of law firm culture.

\section{The Modern Law Firm Market}

\section{Corporate Client Demands}

"Until recently," says professional services consulting firm Hildebrandt International, "the legal profession operated much like a medieval guild. Lawyers were upstream of their clients and could determine the quality of legal services, the pace at which they would be delivered, and the costs. Not any more." (Henning 2007) Legal costs have increased significantly for corporations in recent years. Among the most significant reasons are an increase in regulation; a rise in cross-border activities, which bring into play legal provisions from more than one country; a larger number of complex global transactions and lawsuits; and the legal issues raised by the accelerated pace of technological development. In response, corporations are placing increasing demands on firms to provide services more efficiently at 
lower cost. The market for law firm services thus has become more intensely competitive than ever before.

\section{Market Segments}

When we look more closely at this market, we see that any given moment there is a hierarchy of practice areas; "different legal services command different market values." (Henning 2007) As one moves up the hierarchy, the work is more valuable to the client and its price becomes less significant. As one moves down, the work decreases in significance and increases in price sensitivity.

Work at the top of the pyramid involves innovative cutting-edge practice that is customized to the needs of a particular client, which is typically a major corporation. This work involves crafting novel transactions, fashioning new methods of resolving disputes, or devising creative responses to regulatory requirements. It may involve, for instance, the creation of a publicly traded partnership for a private equity fund in order to obtain both favorable tax treatment and limitations on shareholder rights. (Beck 2007) It may involve major litigation in which the future of the company is at stake, such as a criminal investigation or a major intellectual property lawsuit. It could involve an expedited large corporate bankruptcy, such as the recent reorganization of General Motors. Clients place a high value on this kind of work, and generally have little concern about how much it costs to obtain it. Competition among firms is less on price, and more on reputation for intellectual creativity and innovation.

The second level on the pyramid is work for clients who "rather than needing the profession's most creative talent, want[] to find a firm that [has] accumulated experience in handling certain types of problems" and doesn't need to start from scratch. (Maister 1993) The higher niche of this segment contains practices such as intellectual property, complex securities 
and class action litigation, and large merger and acquisition work. The lower niche includes small to medium size merger and acquisition work, most banking matters, most environmental matters, general corporate work, commercial litigation, most labor and employment matters, and much commercial real estate work.

Finally, the lowest rung of the pyramid is work that is relatively routine, which can be divided into discrete tasks that involve standard procedures. This includes residential real estate, worker's compensation matters, small employment cases, some patent prosecution, foreclosures, loan documentation for banks, general negligence and simple tort cases, and standard insurance defense work.

These are of course broad classifications. A corporate acquisition may be a crucial first tier matter for one company, which is willing to pay what it takes for the transaction to go through, but a more routine matter for a larger company, which will be more sensitive to price. Similarly, patent litigation may involve technology that is integral to a company's operations, which makes its outcome critical, or a patent that less significant, which means that costefficiency will be more of a concern. It's also important to recognize that firms may be very profitable performing work that occupies various rungs on the pyramid. Doing a large volume of commodity work, for instance, may generate quite substantial revenues and profits. The main point is that different types of work have different value to clients, and are subject to varying degrees of price competition.

\section{Structural Implications}

Each level on the pyramid requires distinctive policies across a range of law firm dimensions. Top-tier work requires a high percentage of senior lawyer time, which means that leverage -- the ratio of lawyers to equity partners -- will be low. In turn, the low leverage 
generally means that the firm can afford to grow at a relatively slow rate. Hiring standards focus on the top students from elite law schools who have conventional prestigious credentials such as participation on law review and judicial clerkships.

Compensation for both partners and associates engaged in top-tier work will be high, on the theory that this is necessary in order to attract and keep the best talent. Firms often use a strict up-or-out promotion system for associates involved in this type of practice in order to signal to clients the selectivity and high quality of its lawyers. Firms may be able to charge premium rates for high-end work, or even eschew hourly billing altogether and charge fees that reflect a percentage of the value of a given matter.

Mid-tier practices place more emphasis on the firm's collective knowledge based on past engagements in a given field. Less of the work involves fashioning unique solutions to novel problems, with more of it focused on "executing increasingly predictable (if still technically demanding) tasks." (Maister 1993) This means that more junior lawyers can be involved than in first-tier work, so leverage is higher. Work at this level is especially likely to use time and expense billing; ideally, the profit from increased leverage offsets the lower billing rates. The firm may be able to use contract lawyers or paralegals for some components of this work.

The firm's systems and procedures constitute an important part of the value that it provides in mid-tier matters. Lawyers who work at the firm for a few years become valuable because they are familiar with its modus operandi. This generally means that a firm that performs this kind of work is more likely to establish categories of permanent salaried lawyers rather than adhere to a strict "up-or-out" policy. The firm also is likely to rely on formal training, encourage specialization, and to have formal departments that collect and disseminate the knowledge that the firm acquires. 
Finally, work on the commodity rung competes mainly on the bases of price, reliability, and speed. Because the features of the service are relatively standard, price is an important consideration when corporate clients shop for commodity work. The regular volume of the work may enable the client to estimate its likely cost, and to require a firm to perform the work for a fixed fee. This creates an incentive for a firm to achieve efficiencies by staffing engagements with the most junior employees possible, using contract lawyers, sending some functions overseas, and substituting technology for labor whenever they can. Even more than with midtier work, the value of the firm's services is based on its systems and procedures and the quality of its monitoring and supervision.

\section{The Legal Services Life Cycle}

The legal services that occupy each level of the service value pyramid change over time, as competitive pressures constantly push work toward the commodity end of the spectrum. As competition in a given practice area increases, firms seek to be more cost-efficient in providing the services in that practice. They disaggregate legal work into as many discrete routine tasks as possible, assign them to the most efficient provider, then reassemble the components for analysis by lawyers who add value to them by applying higher-order skills. Even high-end projects may have discrete components that can be performed by low-cost workers following a prescribed routine. (Susskind 2009). Incentives to engage in disaggregation are increasing as more clients seek alternatives to hourly billing, such as fixed fees per project or fees contingent on outcomes.

What was done by an associate twenty years ago, for instance, is now done by a contract attorney, a paralegal, a foreign lawyer or non-lawyer in a low-cost wage jurisdiction, or a sophisticated software system. One indication of this trend is the substantial increase in outsourcing many functions to vendors in either the United States or abroad. (Daly \& Silver 
2007) Increasingly, these functions include not only non-legal activities such as document review, but legal research and brief-writing as well.

The result is a rapidly accelerating legal service life cycle. Much legal work that begins as cutting-edge, high-margin work done by a small number of firms matures into a more standard service that many firms can provide at decreasing cost. The cycle consists of (1) the development of an innovative service that generates above-market profits for its creator; (2) the enjoyment of premium profits by the first mover for a period of time; (3) the entry of additional firms into the market who seek to gain competitive advantage through more cost-efficient provision of the same service; (4) the standardization of many or even all facets of the service in furtherance of this goal; and (5) the transformation of the service into a commodity that corporate clients purchase mainly on the basis of price, with low profit margins for providers. As professional services consultant David Maister has observed, "In every profession, one can point to practice areas that, in only a few short years, moved rapidly from being frontier activities handled by only a handful of innovative firms to high-volume practices offered by increasingly large numbers of competent firms." (Maister 1993)

This process can unfold in litigation, transactional work, or any other type of matter. The widespread availability of information and analysis on the Internet, innovations in global communications technology, and developments in work flow software and supply chain management have all served to shorten the length of the cycle.

\section{Law Firm Strategy}

Law firms face critical choices in determining how best to compete in light of these features of the market. Corporate clients are increasingly sophisticated about what level of service they need for any given matter. A company willing to agree to premium billing for a 
high-end matter will balk at this type of fee arrangement with the same firm for a matter that it regards as less significant. A company that uses a firm for matters on the intermediate level of the pyramid will use a different firm that is more cost-efficient for routine matters. As a result, many law firms nowadays find it difficult to succeed as "full service" firms that contain practices that span the full length of the value pyramid. Firms with business strategies that focus on particular segments of the pyramid are likely to be able to offer more effective and cost-efficient services than firms that purport to provide all services to all types of clients.

Furthermore, attempting to be a full service firm creates managerial difficulties. Different value segments require different policies with respect to matters such as leverage, firm growth, recruiting, promotion, fees, compensation, the availability of permanent lawyer positions, and the use of contract lawyers, paralegals, and technology. In addition, "a consistent image in the marketplace is a valuable asset, which can be rapidly compromised if the firm attempts to serve too diverse a set of client needs." (Maister 1993) It is difficult, for instance, for a firm to create a strong reputation for high-end work when it is already well-known known for its efficient provision of routine services.

For these reasons, law firm consultants recommend that a firm start its strategic planning process by identifying the "value position" of its practices on the pyramid, and that it attempt to ensure that most of its work occupies that rung. Ideally, a firm will develop a strategy "to deliver its core services within a similar range of value positions." (Henning 2007) This will allow it to attain some internal consistency among its various management policies, and to develop a distinctive reputation within the legal services market.

While firms may adopt this goal, most do work in a mixture of segments. One challenge firms face in attempting to focus on a particular market is that practice areas don't occupy a 
stable position on the pyramid. The increasingly rapid pace of the legal services life cycle reflects constant pressure on practices to move toward the commodity end of the spectrum. Furthermore, different practices may move at different rates. A firm that had a roughly equal mix of high-end and mid-tier work last year may have a higher percentage of mid-level work this year, even though its practice areas have remained the same.

Firms have to decide how to respond to this life cycle. One option is to stay with practice areas as they move down the pyramid, revising the firm's organizational structure and policies to adapt to the shift. This does not necessarily mean that the firm will be less profitable; commodity work can be quite lucrative if the firm has enough volume. A second option is to try to maintain a firm with practices at various stage of the life cycle. This response creates significant challenges, since "conflicting economic, behavioral, and management requirements of different practice areas" can create "severe internal tensions and stresses." (Maister 1993)

A third response is to reduce investment in, and eventually abandon, practice areas as they mature. Simultaneously, the firm attempts to move into new practices that can at least preserve, if not improve, the value position of the firm. Firms that aspire to national and/or international prominence attempt to use their highest-value practices as a platform for moving up the pyramid toward premium billing. Representing financial institutions tends to offer an especially valuable opportunity to be involved in high-end matters because of those clients' continuous involvement in business transactions and their ongoing demand for innovative financing arrangements.

Law firms therefore must be sensitive to the position they occupy on the service value pyramid, and must consider when and to what extent the services they provide are likely to become commodities. While they may respond to this likelihood in different ways, most major 
firms attempt to shed practices that migrate toward commodities and seek to use other practices as a platform for moving up, or at least not moving down, the pyramid. The goal for many firms is to increase the proportion of high-end work and reduce the amount that is price-sensitive.

In addition to segmentation, there is some evidence that the law firm market is undergoing consolidation. As the American Lawyer has put it, among the 100 firms with the highest gross revenues, "on the revenue per lawyer chart, the best measure of how successfully firms attract premium work, the top quintile is pulling away from the rest of the firms." (American Lawyer 2007) This may increase the already growing number of law firm mergers and acquisitions, as large firms use their profits from high-end work to expand their share of the overall market. Those firms that hope to remain independent will face the need to identify the market niche they serve and how to focus their practices and align their policies around it.

\section{Organizational Dynamics}

Law firms' attempts to respond to competitive pressures are complicated by the fact that no major organization functions as a single actor that analyzes information, weighs alternatives, and selects the best option. Describing law firm behavior as a straightforward response to business demands neglects this insight. Research underscores that organizations face significant challenges in integrating members into a common culture, that they can send informal signals that weaken or undermine official policy while fostering behavior that may inflict harm on the organization or third parties, and that they establish routines and narratives that can reinforce individual tendencies to rationalize what an outsider would regard as problematic behavior.

First, organizations contain multiple groups with their own agendas, resources, and bases of influence. These groups may be only imperfectly integrated into the organization because of their members' identification with particular business units, project teams, occupations, 
geographical locations, or other sources of affiliation. They may create distinct subcultures with their own cognitive filters, goals, norms, and ways of doing things, which may reinforce or undermine the ostensible mission of the organization. Organizations therefore may not necessarily respond in systematic fashion to market forces as integrated rational actors. This can make it perilous to claim in any straightforward way, for instance, that specific misconduct reflects a considered decision on the part of an organization to cut corners for the sake of earning profits.

Sounding this note of caution is especially important when analyzing law firms. Despite its organizational complexity, a business corporation has an official chain of command, which at least formally specifies who has authority over whom on what issues. One manager can order another to act in a certain way, even though this doesn't guarantee that the order will be carried out precisely as the superior intends. In a law firm, however, individual lawyers retain a considerable amount of power based on their relationships with clients. (Nelson 1988) This can enable them to veto or resist managerial directives, because partners who generate substantial business generally are free to leave and take clients with them if they are unhappy. Lawyers also typically work in specialized practice groups, whose work may be only moderately understood by other lawyers in the firm. These practice groups may generate their own distinct subcultures, as may offices of the firm located in different cities or countries. Furthermore, sustaining a common culture is especially challenging in many firms because of the large number of lawyers who enter and leave the firm via the lateral market. New arrivals may come from firms with significantly different cultures, and the rapid pace of modern law practice can lead the firm to devote insufficient attention to socializing and integrating them into the firm's way of doing 
things. These centrifugal forces mean that law firm leaders typically must rely on persuasion and negotiation rather than formal authority to influence fellow lawyers.

A second consideration that complicates the analysis of law firm behavior is that even organizations with a set of formal goals on which there is a relative consensus may informally transmit signals that are in tension with those aims. Members of an organization are keenly sensitive to which behavior is actually rewarded and which is disfavored, regardless of what official policy may say. An organization may have an elaborate legal compliance program in place to prevent overcharging customers, for instance, but have a system in which the lion's share of compensation is based on commission. Similarly, Enron had a comprehensive Code of Conduct, but also fostered a culture in which risk-taking was valorized and a certain percentage of employees was terminated every six months. Under such circumstances, employees quickly grasp that how the organization allocates benefits and punishments is a better indication of its values than whatever formal rules it has adopted.

Different types of organizations will encourage different kinds of behavior. Relevant to law firms, "knowledge and service-based firms in markets with relatively low barriers to entry and high rewards for innovation" may be especially likely to create a culture that encourages risk-taking. (Langevoort 2002). Those who rise to the top in the tournament-like competition within these firms are likely to take risks because they are optimistic, persistent, and competitive - but also are prone to be overconfident that they can manage the risks that they take. We would expect to find these traits among many law firm partners, since firms provide knowledge-based services and tend to be internally organized as tournaments in which lawyers compete for promotion to partnership. (Galanter \& Palay 1991) The combination of weak integration into firm culture and an appetite for risk can result in behavior that promises individual benefits but 
creates the possibility of serious damage to the firm or third parties. It may not be accurate to describe such behavior as the result of an explicit decision by the firm. At the same time, the conduct is consistent with the risk-taking culture that the firm has propagated.

Finally, any attempt to explain misconduct needs to appreciate that individuals have powerful impulses to avoid interpreting their behavior as ethically questionable. We often are susceptible to self-deception when confronting situations that call for moral judgment. "By avoiding or disguising the moral implications of a decision, individuals can behave in a selfinterested manner and still hold the conviction that they are ethical persons." (Tenbrunsel \& Messick 2004) A variety of devices can lead to "ethical fading," a process in which we elide the morally significant features of a situation by repressing awareness of them. (Tenbrunsel \& Messick 2004) This allows us to frame a setting as one that raises, for instance, practical business questions but not ethical ones.

A phenomenon that can contribute to ethical fading is the tendency to rely on organizational "schemas" and "scripts" in processing large amounts of complex information. A schema is "a cognitive framework that people use to impose structure upon information, situations, and expectations," which allows "virtually effortless interpretation of information and events." (Gioia 1992) A script is specialized type of schema that provides guidance with respect to specific contexts. As Gioia suggests, relying on scripts "is a default mode of organizational cognition," in which decision makers interpret information "in a mode that is akin to "cruising on automatic pilot." (Gioia 1992). As a result, "[i]f a case involves a familiar class of problems or issues, it is likely to be handled via existing cognitive structures or scripts - scripts that typically include no ethical component in their cognitive content." (Gioia 1992; emphasis in original) Organizational routines and procedures thus can enable individuals to process large 
amounts of ambiguous information, but their very effectiveness may dampen appreciation of ethically salient features of a situation. They can enable an actor to rely more on rapid intuition in interpreting events. This can be dangerous, because "it often is the case that the acts that can originate unethical chains of occurrences arise from the quick decisions that are products of the intuitive judgment system," rather than "the more deliberative reasoning system." (Darley 2005).

\section{Jenkens \& Gilchrist}

Appreciating differences in the value and price sensitivity of practice areas, the operation of the legal service life cycle, and increasing segmentation and consolidation can give us distinctive insights into the business pressures that modern firms face. Awareness of organizational dynamics can make us sensitive to the complex behavioral roots of law firm responses to these pressures. At the same time, we must recognize that even these concepts are fairly general, and that there is no direct correlation between a particular variable and specific behavior by law firms and the lawyers within them. To understand events surrounding a particular firm, we need an even more fine-grained analysis that is guided by these concepts but that takes account of inevitably unique circumstances. In what follows, I rely on this approach to offer some observations about the rise and demise of Jenkens \& Gilchrist.

\section{Early History}

Jenkens \& Gilchrist was founded in 1951 by Holman Jenkens and William H. Bowen. Jenkens had served since 1946 as the personal lawyer of Clint Murchison, Jr. The Murchison family was active in the oil business and other ventures, and was an influential member of Dallas society. The firm's stable long-term relationship with the Murchison family was a common feature of law firm practice in the middle part of the twentieth century. 
Although it expanded as the Texas economy grew, Jenkens was a small high-end firm that expected to stay relatively small. By 1985 , the firm had grown to 125 lawyers, but $20-30 \%$ of its business still came from the Murchisons. The firm was known as collegial and friendly. It typically did not cut the compensation of lawyers whose billable hours fell temporarily due to marital or health problems. In this respect, the firm was similar to other firms during the period whose stable client base and insulation from stiff competition allowed them to avoid relying on financial considerations as the driving force of their decisions.

\section{The Downturn}

Jenkens' halcyon existence was destroyed in the mid-1980s with a sharp decline in the Texas economy provoked by failures in the energy, real estate, banking, and savings and loan sectors. The firm also faced litigation by the Federal Savings \& Loan Insurance Corporation (FSLIC) over its representation of two savings and loans that had failed. In addition, it was a defendant in a lawsuit by twenty-six investors who had lost money from participation in a failed oil project that Jenkens had assisted in making a private stock offering in 1981. The firm settled with the FSLIC for \$18 million in 1989, and was found liable for just under \$6 million in damages in the investor lawsuit.

The combination of the business downturn and legal troubles left Jenkens in a precarious position. The firm had cultivated a client base mainly of influential companies and wealthy individuals in Dallas. To a large degree practice was organized around clients at least as much as around practice areas. The firm provided a wide range of services for these clients. The clientoriented organization of practice and the firm's relative insulation from significant competition meant that Jenkens' leaders likely spent little time thinking of the firm's market position. 
By the end of the 1980s, however, this business model was no longer viable. The firm could no longer concentrate its work on a single geographic market or in a limited number of industries. Nor could it count on long-term relationships with clients any more, since corporations had begun to sever exclusive relationships with firms and to foster competition for business. Finally, Jenkens was handicapped in moving forward by the fact that authority was dispersed in the firm among a large executive committee. As a result, many in the firm were uncertain whether the firm could survive.

\section{Recovery and Growth}

Faced with the possible demise of Jenkens \& Gilchrist, a group of young partners sought to develop a strategy that addressed the firm's predicament. The first priority was revising the firm's governance structure. They eventually proposed, and the firm adopted, a three-person executive committee (later expanded to five) and a strong president. These members would be advised by an electoral committee consisting of the heads of major practice groups.

At the end of 1989, 41-year-old David Laney became president of Jenkens \& Gilchrist. Laney was from a prominent Dallas family. His father for many years was president of the major Dallas law firm now known as Locke, Liddell \& Sapp, and his mother was the granddaughter of the founder of the Dallas Morning News. Laney began to chart a course for the

firm that he believed would allow it to succeed in the new legal services market. One important objective was to diversify both geographically and in terms of practice areas. Another was to identify and expand in those practices that were likely to be most lucrative. The firm also was determined to revise its compensation to compete more effectively with the large Houston firms. The last was a challenge, however, because Dallas for the most part had a "mid-market" client base. Companies generally were not as large, diverse, and prosperous as the ones in Houston. 
This meant that Dallas firms often were unable to bill at rates as high as the firms in Houston because their clients simply could not afford it. This in turn constrained the firm in compensating its lawyers.

The next step in remaking the firm was to let go a quarter of its lawyers, reducing it from 225 to 165 . Laney later reflected, "It was a low point, one of the lowest in my life, but for the firm, it was a galvanizing point, and in retrospect, inescapable.” (Granberry 2000) The firm then began to recruit lawyers from other firms who practiced in intellectual property, construction and government contracts, franchise law, health law, government relations, and tort litigation. The intellectual property practice area was especially profitable, and represented a movement into at least a high niche in the mid-tier market. By 1998, the firm had increased the number of lawyers in this field to seventy, compared with just five in 1994. Through much of the 1990's Jenkens acquired practice groups of various sizes, expanding beyond Dallas and then beyond Texas. In 1992, Jenkens opened a Washington, D.C. office, and in 1997 it opened one in Los Angeles.

In 1996, Jenkens moved into The American Lawyer's AmLaw 100 in gross revenue and profits per partner. It ranked $98^{\text {th }}$ and $64^{\text {th }}$ in these categories. By 1998 , Jenkens stood at 340 lawyers. It had hired more than 180 lawyers over the previous three years. This $86 \%$ growth rate led the National Law Journal in early 1998 to describe the firm as a "juggernaut," and to name it the fastest growing law firm in the United States. Reflecting this jump, the firm moved to 68 in the National Law Journal ranking of the largest 250 firms in the country, up from 166 in 1994.

The January 1998 National Law Journal article on Jenkens noted the firm's rapid addition of practice groups from different firms as the basis for its growth, saying that Laney 
"inspired these lawyers to dream Texas-size dreams." (Klein 1998) It suggested that "being rewarded for rain appears to be what lured many newcomers," quoting one lateral's dissatisfaction with other firms that compensated lawyers based on seniority. Another attraction of the firm was that branch offices set their own budgets, decided what areas in which to specialize, and made associate hiring decisions independent of Dallas.

For many at the firm, the next challenge was to "develop a national presence." (Klein 1998) The board was investigating the possibility of entering the New York market, and the head of the intellectual property practice said that the firm almost certainly would be moving into the Silicon Valley. "He has expectations of us being the largest technology 'boutique' in the country," the lawyer said of Laney. "David Laney doesn't stop at being No. 10.” (Klein 1998)

It's worth looking more closely at Jenkens \& Gilchrist at the time the National Law Journal profile was written in early 1998, since it provides a portrait of the firm just a few months before it hired tax shelter lawyer Paul Daugerdas. Jenkens was a regional firm that had national aspirations. Like most regional firms, most of its work was in the middle tier of the value pyramid, although some intellectual property litigation conceivably could be high-end work. The desire to diversify led the firm to feature a total of thirteen practice groups by 1998 . Some of those likely were not as profitable as intellectual property, but they generated revenues and were a hedge against falling victim to reliance on too narrow a practice base. Jenkens thus pursued a strategy of strengthening and diversifying its mid-tier practices, while looking to add lawyers in practice areas and locations that might give it a foothold on the top level of the pyramid.

The legal services market in Dallas was especially robust at this time, but there was strong competition from peer firms in the city that were following a similar business strategy. 
The belief was that firms had to grow quickly to survive. This meant that acquiring laterals, rather than organic growth from within, was the best way to diversity and expand the firm's economic base. The firm made itself attractive to laterals by insisting on merit-based compensation that rewarded business generation. Because of intense competition in the regional market, expansion beyond Texas and the Southwest was important.

Crucial to success in the lateral market was the firm's profits per partner (PPP). If Jenkens were to realize its ambitions to become a national firm, this figure had to be increasing. Recruits automatically asked the firm about its balance sheet and profits when considering an offer to relocate to Jenkens. If the firm hoped to crack the New York market, keeping PPP up would be especially important, given the profitability of firms in that market.

The most recent figures from The American Lawyer at this time indicated that the firm ranked $84^{\text {th }}$ in the AmLaw 100 in gross revenues in 1997 , posting a $30.6 \%$ increase over the previous year. This was the third-highest gain among AmLaw 100 firms. More troubling, however, was the firm's PPP. By the end of 1998, when Jenkens was considering whether to extend an offer to Daugerdas, the firm was about to close the books on a year in which it would drop from $75^{\text {th }}$ to $79^{\text {th }}$ in the AmLaw 100 with profits per partner of $\$ 390,000$. This figure was only $0.3 \%$ larger than in 1997. More ominously, the gap between the AmLaw 100 average firm's profits per partner and Jenkens' had increased during the year from $\$ 212,000$ to $\$ 232,000$.

Furthermore, in its description of the 1998 Texas legal services market, The American Lawyer noted that increasing competition was coming from out-of-state firms. "The past few years have been a period of consolidation," said the publication, "as firms look to beef up their ranks in order to compete." (American Lawyer 1999) During the year, Dallas' Locke Purnell Rain Harrell and Houston's Liddell, Sapp, Zivley, Hill \& LaBoon had merged to create the fifth 
largest firm in the state. Its combined revenue would have ranked it in the AmLaw 100 for 1998. Boosting profits at Jenkens thus was critical in order to fund the continued growth that was seen as necessary in order to survive in a consolidating market.

Jenkens \& Gilchrist at this point was a very successful firm by almost every measure. It was one of only two Dallas-based firms in the AmLaw 100. It had weathered the crisis of the late 1980s and embarked on a path of substantial growth in size and revenues. If Jenkens were to compete on a national stage, however, this was not enough. It had to figure out a way to boost profits per partner high enough that it could compete for laterals with other AmLaw 100 firms, as well as defend itself from firms seeking to raid its own partners. In late 1998, Paul Daugerdas approached the firm with a proposal that seemed to offer a chance to do just that.

\section{The Taxman Cometh}

\section{The Decision}

In late 1998, Paul Daugerdas was a tax lawyer and CPA who worked at the law firm of Altheimer \& Gray in Chicago, where he had been since 1994. Daugerdas formerly had worked at Arthur Andersen, and had developed a tax shelter practice at Altheimer.

A tax shelter is a transaction that results in a loss, which the taxpayer then uses to reduce taxable income. This is permissible if the taxpayer incurred the loss in an effort to produce income, or while engaging in an activity that Congress wants to favor, such as investing in lowincome housing. The IRS regards a shelter as abusive, however, and will disallow the loss, if the transaction is not one that Congress expressly wants to encourage, and it has no economic consequence or business purpose other than to reduce taxes.

In a well-known case, for instance, an owner of 1,000 corporate shares sought to minimize the taxes she would pay on profits from their sale. She first transferred the shares to a 
newly-formed corporation of which she was the sole owner. This new corporation then dissolved, and distributed the 1,000 shares to her. When she sold the shares, she argued that she had received them in a corporate "reorganization," which resulted in an especially low tax on her profits. The Court, however, ruled that the creation and dissolution of the new corporation was not a genuine reorganization. The corporation was not created to engage in any business, but was a "contrivance" to lower the taxpayer's taxes. As the Court noted, "When that limited function had been exercised it immediately was put to death." (Gregory v. Helvering 1935) The requirement of economic substance is deemed necessary to safeguard the integrity of the tax system, whose ability to raise revenue otherwise could be eviscerated by manipulation of its complex provisions in a manner that Congress could not have foreseen or intended.

In the early and mid-1990s, financial institutions and accounting firms had begun to create tax shelters on their own initiative and to market these "products" to corporations and wealthy individuals. (Rostain 2006) When Daugerdas came to Altheimer, the firm had a traditional tax practice designed to minimize the tax consequences of transactions that originated elsewhere in the firm. He changed the focus of Altheimer's tax practice to a "tax products" practice, and eventually became chair of the firm's tax department. (Braverman 2003) Aside from designing tax shelters, Daugerdas' major role was to provide an opinion to shelter purchasers that a shelter more likely than not would be upheld by the courts if ever challenged by the IRS. This type of opinion is intended to protect the taxpayer from having to pay a penalty if the IRS claims that the shelter is abusive and disallows the reduction in taxable income resulting from it.

By late 1998, Daugerdas was dissatisfied with his compensation arrangements at Altheimer. His work made firm leaders nervous, however, and when he agitated for more 
compensation, they didn't make a serious effort to accommodate or to keep him. Daugerdas then approached Jenkens \& Gilchrist, having learned about the firm in the National Law Journal article describing it as the fastest growing law firm in the country. He described a tax shelter that he had devised, claiming that he could generate as much as $\$ 6$ million in annual revenue by charging wealthy clients a percentage of the taxes they saved by using the shelter. This was substantially more than firm partners were generating billing by the hour.

Aside from the revenues that it generated, tax shelter practice was especially attractive to a firm with national ambitions. It effectively offered Jenkens \& Gilchrist a foothold in the highend market segment without the need to fashion customized solutions to clients' needs. Because of the magnitude of the promised tax savings, investors were price-insensitive. A tax shelter was presented to an investor as a customized transaction that would reduce that investor's tax liability. The taxpayer was prevented from shopping around to see if another firm could offer this service more cheaply, and generally did not have the expertise to evaluate how the transaction compared to other arrangements for reducing taxes. Although the tax shelter in reality was a commodity that was marketed to several hundred taxpayers, the firm was able to mimic providing a high-end service by avoiding the need to compete on the basis of price.

In addition to the appeal of a tax shelter practice, Daugerdas' overture was of interest to the firm because it offered an opportunity to move into Chicago. Firm leaders regarded that city as especially suitable for Jenkens because much of the practice there was for mid-market clients, who still comprised the main foundation of the firm's practice.

Daugerdas made clear that he wanted to be compensated from the revenue that he himself generated, at a percentage above the typical share that shareholders at the firm received. His revenue therefore would be tracked separately from the rest of the firm's. This was a departure 
from the firm's system, in which partners were compensated according to a percentage of the firm's overall profits.

The discussion within the firm about whether to extend an offer to Daugerdas was vigorous, especially among the tax lawyers. (Fairbank \& Maxon 2007) There were arguments on both sides about the validity of the shelters under the tax law. On one side, some emphasized that supposedly reputable major accounting firms were selling these products, and were heavily recruiting lawyers to help with them. There were no IRS rulings or court decisions disallowing the specific type of shelter that Daugerdas was marketing. Others disputed Daugerdas' interpretation of the law. They also argued that even if there were technical arguments in support of the shelters, there was a substantial risk that the IRS would disallow them and that taxpayers would have to pay penalties. This could expose the firm to malpractice lawsuits, and might stain its reputation. Some tax lawyers also argued that the firm was not in a position to monitor Daugerdas' work effectively, because doing so required intimate familiarity with the arcane details of this highly technical area of tax practice. In addition, Jenkens was not able to speak to anyone at Altheimer \& Gray to determine if Daugerdas' personality would be a good fit, because Daugerdas didn't want that firm to know that he was considering leaving.

Ultimately, proponents of Daugerdas prevailed. Management saw the major risks from Daugerdas' work as the chance that his shelters would be disallowed and that the taxpayer would sue the it. The likelihood of a malpractice action was similar to the type of risk that any other practice area posed, which the firm felt that it could handle with appropriate diligence. Jenkens had enjoyed success in bringing in a substantial number of laterals over the past several years. This gave management confidence that it could smoothly manage the arrival of Daugerdas if it put in place a system for supervising the tax shelter work. Under this 
arrangement, Michael Cook, a well-respected tax lawyer in the firm's Austin office, would have to sign off on all tax opinion generated by the Chicago office. Cook was regarded as someone who would not hesitate to oppose anything that he regarded as a problem. By taking this step, management contended that the firm would be protected from the risk posed by Daugerdas' practice.

\section{Daugerdas at Jenkens}

From the start, Daugerdas' tax shelter work was the focus of the Chicago office. His position was managing shareholder in Chicago and head of the Structured Investment and the Tax \& Estate Planning Group. The shelter that generated most the fees involved generating artificial losses through offsetting foreign currency options -- one to buy currency, the other to sell -- funneled through partnerships or private companies. When the options were sold, this triggered a capital loss to the taxpayer, even though the taxpayer's actual net economic cost of participating in the transaction was negligible. The taxpayer's losses were then claimed as offsets to taxable income. (Browning 2004)

Daugerdas helped create the shelter, while accounting firms sold it. Every time a shelter was sold, Jenkens \& Gilchrist created the necessary entities and issued a virtually identical letter opining that the taxpayer more likely than not would prevail if the shelter were challenged by the IRS. Jenkens received around 3\% of the promised tax savings, with the accounting firms receiving $1.5 \%$, and banks handling the currency trades an additional 1.5\%. Buyers were required to use Jenkens \& Gilchrist, but they never met Daugerdas or any other Jenkens lawyer. In its later suit seeking the names of investors, the IRS estimated that about 600 people invested almost $\$ 2.4$ billion in the shelters. (McCollam 2003) 
Henry Camferdam was one business person who invested in a Daugerdas shelter. After selling his business for a $\$ 70$ million gain in August 1999, Camferdam received a call a few months later from Ernst \& Young, who was his auditor and consultant. The representative said that the firm could help him erase his capital gain for tax purposes. At a follow-up presentation, Camferdam was given a form to fill out asking how much of a loss he wanted to create. The accounting firm told him that Jenkens \& Gilchrist would provide an opinion to him that would serve as "insurance" in case of an IRS audit. Brown \& Wood would supply a second opinion "just to make sure."

Camferdam was not permitted to have his regular law firm look at the shelter, nor to make copies of the paperwork. He was not told that Jenkens was offering an opinion on a shelter that it had created, nor that the firm had entered into arrangement with Ersnt and Deutsche Bank to sell the shelters. He never spoke with any Jenkens lawyer, but wired a little more than $\$ 2$ million to the law firm, which represented 3\% of his $\$ 70$ million tax savings. He paid a total of \$6 million in fees to participate in the transaction.

Daugerdas' activity had an immediate effect on the profitability of Jenkens \& Gilchrist. In 1998, the first full year in which he was at the firm, his practice generated almost $\$ 28$ million in revenue. The firm had ended 1998 with gross revenue of $\$ 140$ million and profits per partner of $\$ 390,000$. Those figures jumped dramatically in 1999 . Gross revenue increased by $43 \%$ to \$200 million, and the firm moved from $77^{\text {th }}$ to $57^{\text {th }}$ on this metric in the AmLaw 100 .

Even more important, profits per partner increased in 1999 by $36 \%$ to $\$ 530,000$. This moved the firm up 17 places in the AmLaw 100, from $79^{\text {th }}$ to $62^{\text {nd }}$. It also placed comfortable distance between Jenkens and its main Dallas-based rival Locke Liddell \& Sapp, which had vaulted into the AmLaw 100 for the first time in 1999. Daugerdas had dramatically boosted 
Jenkens' odds of realizing its ambition to become a major national, and possibly international, law firm. Indeed, the firm would be emboldened to enter the New York market in late 2000 by merging with the firm of Parker Chapin. From 1999-2003, the Jenkens Chicago office tax practice generated \$267 million in fees from shelters. Of this amount, the firm received a third, Daugerdas $\$ 93$ million, and his Chicago colleagues Mayer and Guerin $\$ 28$ million and $\$ 4$ million, respectively.

Notwithstanding the considerable revenue he generated, Daugerdas was a source of some friction within Jenkens. He frequently disagreed with the firm's board over the compensation that he, Mayer, and Guerin received, which provoked some ugly confrontations. Daugerdas also repeatedly locked horns with Michael Cook concerning his tax shelter work. "I would regularly get a read that it was increasingly unpleasant dealing with Daugerdas," recalls Laney. "It was a very difficult interaction, and it grew increasingly difficult. Mike would say, 'No, you can't do it this way.' Paul didn't like to have his opinions tinkered with." (Koppel 2007)

Unknown to Jenkens, Daugerdas had an interest in a company called Treasurex Financial Ltd., which separately received additional fees from tax shelter clients. In a subsequent dispute with Diversified Group, Inc. (DGI), a tax shelter company with which Daugerdas worked to design shelters during his time at Altheimer, Daugerdas testified that Treasurex acted as an intermediary to bring buyers and sellers together. He acknowledged that no one at either Jenkens or Altheimer knew about the payments to the company.

The disclosure of Treasurex, coupled with Daugerdas' difficult personality, prompted Jenkens chair David Laney to conclude that Daugerdas should leave the firm. Laney recommended this to the board and asked for two straw votes in late 2001. In each case, five of the six board members favored asking Daugerdas to leave. But the board didn't act. It was the 
fourth quarter of the year, and the firm was concerned about collecting on clients' unpaid bills, Laney later said. The board feared that firing Mr. Daugerdas would have disrupted the tax lawyer's own collection efforts and distracted the entire firm, he said. Laney continued, "We wanted to wrap up the year in good shape," then take action the following year. (Koppel 2007a) By then, however, it would be too late.

\section{Storm Clouds}

There likely was another reason that the firm was reluctant to oust Daugerdas at the end of 2001: the government had begun to ramp up its enforcement against abusive tax shelters. This could make it risky for the firm and Daugerdas to be adversaries. Beginning in late 1999, the IRS awoke after a period of quiescence and launched several initiatives designed to attack what it regarded as abusive tax shelters. Speeches by agency officials from the Commissioner on down deplored the losses to the government from such shelters, and declared that combating them was a top priority. Courts handed the IRS a string of victories in tax shelter cases. The IRS issued several notices classifying specific shelters as abusive, including those that closely resembled the ones on which Daugerdas was working. New regulations stiffened requirements to register and report tax shelter transactions, which generated a flood of information that the IRS began to use to pursue investigations and enforcement actions.

In December 2001, the newly-formed Office of Tax Shelter Analysis reported that corporations had used tax shelters to avoid $\$ 14.7$ billion in taxes in 2001. Later that month, the IRS announced an amnesty program under which taxpayers could voluntarily come forward, disclose tax shelter transactions in which they had been involved, and avoid penalties that otherwise would apply. Such an initiative promised to provide even more information about the professionals who had been involved in designing and marketing these shelters. Thus, 
notwithstanding their differences, under the circumstances it was advisable for Jenkens and Daugerdas to have as cooperative a relationship as possible.

In 2002, the IRS successfully pressured Ernst \& Young to release its list of clients involved in shelters that the government regarded as potentially abusive. One client on the list was Henry Camferdam. The IRS indicated that it was disallowing Camferdam's tax losses resulting from his participation in shelter activity. In late 2002, Camferdam filed suit against several defendants, among them Jenkens \& Gilchrist, contending that Daugerdas and members of the firm knew that the government would treat the tax shelter as invalid. Eventually 1100 class members joined Camferdam's suit, which was consolidated with the suit of Thomas Denney, another tax shelter purchaser. The IRS then issued a summons to Jenkens demanding the disclosure of 600 clients who had been involved in potentially fraudulent shelters. The firm refused to comply, claiming that the attorney-client privilege prohibited disclosure of the names. In May 2004, however, a federal court ordered it to turn over the names.

After fourteen months of negotiations, the firm reached a settlement in the investor litigation in January 2005. The Plaintiffs would receive $\$ 81.55$ million. Jenkens was responsible for $\$ 5.25$ million, Daugerdas for $\$ 4$ million, Mayer and Guerin for a total of $\$ 2$ million, and the firm's insurer for the rest. Malpractice suits by investors who had opted out of the settlement still remained pending in various states.

Meanwhile, the U.S. Attorney's Office in Manhattan impaneled a grand jury to investigate Jenkens' tax shelter activity. As the investigation continued, Jenkens began to shrink. By 2006, the firm was down to 144 lawyers, compared to the 600 or so it had in 2001 . In early 2007, leaders concluded that the firm was likely to dissolve. Management had done its best to 
keep the firm together in hopes of surviving, but also in order to protect employees by effecting an orderly dissolution if need be.

The end came swiftly. On March 29, the U.S. Attorney's Office announced that it had entered into a non-prosecution agreement with Jenkens \& Gilchrist, under which the firm admitted that it had developed and marketed fraudulent tax shelters, and that it had issued fraudulent opinion letters. The US Attorney said that the government's decision to enter into the agreement was based on these admissions by the firm, as well as the firm's "inability to continue practicing law as a firm"; Jenkens' cooperation with the prosecutor's investigation of the tax shelter activities of the firm and its lawyers; and the firm's entry into a settlement with the IRS.

Jenkens \& Gilchrist issued the following statement in connection with the agreement:

We believe that certain $J \& G$ attorneys developed and marketed fraudulent tax shelters, with fraudulent tax opinions, that wrongly deprived the US Treasury of significant tax revenues. The firm's tax shelter practice was spearheaded by tax practitioners in J\&G's Chicago office who are no longer with the firm. Those responsible for overseeing the Chicago tax practice placed unwarranted trust in the judgment and integrity of the attorneys principally responsible for that practice, and failed to exercise effective oversight and control over the firm's tax shelter practice. Our prior support for the opinions adversely affected the efforts of the IRS to assess and collect tax revenues. We deeply regret our involvement in this tax practice, and the serious harm it caused to the United States Treasury. (Jenkens \& Gilchrist 2007)

The same day, the IRS announced that it had reached a settlement with Jenkens under which the firm agreed that it was subject to a $\$ 76$ million penalty due to "the firm's promotion of abusive and fraudulent tax shelters and violation of the tax law concerning tax shelter registration and maintenance and turnover to the IRS of tax shelter investor lists." (Internal Revenue Service 2007) The agency estimated that 1,400 investors received advice from Jenkens and would owe interest and penalties for underpayment of tax. What had been the fastest growing law firm in the country nine years earlier was now out of business. 


\section{Jenkens \& Gilchrist and the Dynamics of Competition}

What insights into these events can we gain by focusing on the particular competitive dynamics that Jenkens \& Gilchrist confronted? First, we need to recognize that Jenkens was a regional firm with a mid-market client base in a national legal services market that appeared to be consolidating and segmenting. As consolidation advances, firms become larger and more diversified, and smaller firms increasingly find it hard to survive as independent entities. Belief in a trend toward consolidation led Jenkens to take the initiative to grow as quickly as possible to attain a competitive scale that would enable it to be one of the survivors. For many Jenkens lawyers, the firm's near-death experience of the late 1980s was seared into their memories. The lesson they took away was that in order to survive the firm needed continually to expand geographically, and to seize opportunities to move beyond its client base toward more lucrative practice areas. Fear of increasing consolidation left Jenkens determined to end up on the right side of the widening market divide.

Segmentation reflects the emergence of distinct legal services submarkets. Important characteristics that distinguish market segments include how rate-sensitive clients are and the extent to which services are priced by the hour. Clients tend to be less concerned with rates for high stakes transactions or litigation, which offers the possibility of charging premium rates or a fee that represents a percentage of the value of a matter. Services in other market segments are subject to varying degrees of client pressure to minimize costs.

Most of Jenkens' work was in the mid-tier market. In this tier, clients regard several firms as capable of providing comparable service, and place considerable weight on price as a 
basis for selecting a firm. In light of this, firms have incentives to routinize as many aspects of their work as possible in order to compete. Firms that operate in this segment thus are especially subject to pressures from the legal services life cycle that move work toward the commodity end of the spectrum. This can result in declining profit margins. Jenkens responded to this dynamic by aiming to grow. Increasing the amount of mid-tier work would help offset declining margins by increasing volume. Increasing representation on high-end matters would involve charging fees for work at an earlier stage in the legal services life cycle, in which pressures toward commoditization were less intense and prices and margins were higher.

All firms are sensitive to profits per partner, but Jenkens \& Gilchrist's strategy of growth by acquisition places particular importance on this metric. PPP is the currency with which a firm competes in the lateral market, both in attracting new partners and in preventing defection by its own. Jenkens' PPP, however, were lagging behind the national firms that it aspired to be. A practice as profitable as Daugerdas' could boost PPP substantially and help the firm lure partners with profitable practices from other firms. This was especially important if Jenkens had any hope of moving successfully into New York. Acquiring Daugerdas thus had great appeal for a firm that built its strategy around transcending its roots to become one of a dwindling number of large firms that emerged in a national legal services market.

Aside from boosting profits, bringing Daugerdas into the firm also would help further the aim of doing more high-end work for which cost containment was not the predominant concern. Not many firms can find such opportunities, especially regional firms whose work is subject to a fair amount of price competition. Daugerdas' practice, with fees based on a percentage of tax savings, effectively provided Jenkens with work based on a version of value billing. It had an appealing combination of features. 
First, fees were based on a percentage of the value of a matter rather than hourly rates. For this work, the firm therefore could escape the constraints of the billable hour and reap a share of the financial benefits that it made available to clients. In this respect, tax shelter billing represents a version of what elite firms like Wachtell Lipton do when they charge a fee based on the value of a merger or acquisition.

Second, after a tax shelter opinion was created, it could be used again for the same type of transaction sold to other taxpayers. The cost of producing the opinion for future transactions was negligible, while the fee as a percentage of tax savings could be substantial. In this respect, the firm would be able to use value billing on transactions that had become routine commodities. The firm would enjoy the benefits that came from high-end practice. At the same time, however, it did not have to incur the cost of designing customized solutions for every client, as did elite firms engaged in work at the top of the value pyramid.

A third feature of tax shelter opinions was designed to insulate them from the competitive pressures of the legal services life cycle that push toward the commoditization of legal work. While higher end work is subject to the least amount of pressure to minimize costs, firms still find it difficult to avoid the legal services life cycle altogether. A firm that develops a cuttingedge strategy for a transaction, for instance, can't keep that work confidential. It discloses the details of its innovation when it distributes documents to all the other parties involved in the deal. As the information becomes more widely known, competitors look for ways to provide the same service more cheaply or to develop superior innovations. The result is that the original firm may enjoy only a brief period when it reaps the lion's share of benefits from its creativity.

Daugerdas' tax shelter arrangements sought to avoid this dynamic by restricting information about the terms of the shelters. Clients were prohibited from sharing information 
about the shelter on the ground that it was a trade secret, and were forbidden to consult any lawyer other than the one recommended by the tax shelter designers. Potential competitors thereby were deprived of the information they needed to compete on the basis of cost-efficiency and price. Indeed, there was some talk of trying to patent the transactions. In any event, treating them as a trade secret prevented what was essentially a commodity service from being priced as one.

Daugerdas therefore had particular allure for Jenkens as a profitable lateral who could provide the firm some respite from the fee reduction pressures to which mid-tier firms are subject. His tax shelter practice, in other words, offered Jenkens a possible path across the great market divide.

\section{A Calculated Gamble}

In addition to appreciating the competitive dynamics that a law firm faces, I have suggested that we can gain a richer understanding of firms by recognizing that they are not unitary entities that behave according to a rational assessment of various alternatives. Daugerdas was attractive to Jenkens for many reasons, but the fact that he would boost the firm's profits and further its business strategy didn't necessarily mean that the firm would unanimously welcome him with open arms. Events played out in a complicated way, and could have taken a different turn. At the same time, it is not difficult to imagine that the potential benefits of Daugerdas' practice and the firm's encouragement of risk-taking caused at least some partners to engage in "motivated reasoning" that prevented them from conducting a dispassionate analysis of the situation. (Kunda 1990) Those who were inclined to extend an offer to Daugerdas had opportunities to rationalize their decision in certain ways that I will describe. Furthermore, partners who were not tax experts were not in a position to engage in detailed disinterested 
analysis even if they had wanted to. This may have diminished their sense of responsibility for the decision, and reduced the prospect of a widespread debate on the advisability of bringing Daugerdas on board.

What seems most plausible is that Jenkens brought Daugerdas on board knowing that he posed some risks, that it put in place a system to oversee the tax shelter practice that was seriously flawed, and that those flaws were exacerbated by the fact that the firm had seriously underestimated the magnitude of the risks that Daugerdas posed and overestimated its ability to manage them.

\section{Identifying the Risks}

Jenkens was aware that Daugerdas came with some risks because the tax lawyers at the firm were deeply divided about whether his tax shelters were legally defensible. Some felt that he had found a legitimate loophole in the law, while others believed that there was a significant chance that the government would find them invalid. There were technical arguments in support of each side of the debate. The larger legal concern of opponents, however, was that the IRS always has authority to deny losses from a transaction that complies with the letter of the law if the transaction had no economic substance or business purpose.

Furthermore, some tax lawyers argued that an IRS challenge to the shelters could taint the reputation of the firm. Prestigious firms historically had been unwilling to be associated with shelters for fear that they would be seen as willing to cut corners too sharply. Raising a concern about reputation thus implicitly suggested that there was an ethical dimension to the firm's decision. There was some indication, however, that the stigma associated with tax shelter work might be fading. Major accounting firms were designing and selling shelters on an unprecedented scale, and some major law firms that previously had refused to provide opinions 
for them now were willing to do so. Furthermore, the IRS at the time seemed relatively unconcerned about the rise of shelter activity. This apparent shift in attitudes undercut the force of any claim that the firm confronted an ethically significant question, and could incline many to frame the situation as calling for a business decision. (Tenbrunsel \& Messick 1999)

Faced with such a strong difference of opinion, management could have concluded that Daugerdas' practice was sufficiently novel that a consensus among tax lawyers was necessary before it would be comfortable with bringing him into the firm. Jenkens had not become the fastest-growing firm in the country by being risk-averse, however. Indeed, the firm's culture valued risk-taking. A more aggressive way to frame the decision was that there was a respectable number of tax lawyers who felt that there was a colorable defense of Daugerdas' shelters. Once this threshold was satisfied, the question was how much risk the firm was willing to take on. Framing the decision in this way could seem plausible because of the moral ambivalence surrounding tax law. On the one hand, paying taxes is a basic civic duty that enables society to function. At the same time, reducing one's taxes as much as possible is regarded as perfectly appropriate rather than morally problematic. As Judge Learned Hand famously put it, "Anyone may arrange his affairs so that his taxes shall be as low as possible; he is not bound to choose that pattern which best pays the treasury." (Gregory v. Helvering 1935) Jenkens might rationalize that in the absence of a clear indication of illegality, it was appropriate to take an instrumental approach to the tax law that focused only on the risk that the IRS would invalidate the shelters.

The firm also knew that Daugerdas posed risks because he was an aggressive personality who pushed boundaries. He was leaving Altheimer because he was unhappy with his compensation. His lucrative practice was not enough to lead that firm to make a serious effort to 
keep him, even though it was apparent that the revenues he generated could justify a higher draw. Furthermore, Daugerdas' demand to Jenkens for his own special compensation arrangement signaled that he was not necessarily inclined to accede to firm policies or culture. Not only did he insist on being paid a percentage of the revenues that he generated, in contrast to every other partner in the firm. He also persisted in a campaign that finally culminated in the firm amending its articles so that his compensation would be paid to a corporation rather than to himself individually. He thus was someone who was tenacious in pursing his interests, both in his practice and in dealings with his partners. Even if his current tax shelter work were defensible, he was the sort of personality who might well push the envelope even further in the future.

A related risk was that agreeing to a special compensation arrangement for Daugerdas would undercut his integration into the firm. Productivity-based compensation systems typically take revenue generation into account in determining the percentage share of profits to which a partner is entitled. The amount to which that percentage is applied, however, is the profits of the firm as a whole. This gives a partner at least some interest in the success of his or her colleagues, since their efforts increase the size of the pot.

For Daugerdas, however, what others in the firm did essentially was irrelevant. His compensation rested upon how much revenue he and his colleagues' tax shelter practice created. In a sense, he could act almost as a solo practitioner who paid the firm a share of his profits to cover administrative overhead and then kept the rest. To say the least, this is not a recipe for instilling in a partner any sense of constraint based on the risks his or her activity might pose for other lawyers in the firm. Jenkens had to know that this situation created a risk for the firm. 
At the same time, the firm might rationalize that the demand for special compensation was not out of line for a successful rainmaker. Such lawyers are not known for being shy. They are entrepreneurial, and aggressiveness can serve them well in building a reputation that attracts clients. Jenkens was known for pushing the boundaries of convention, so an aggressive lawyer with a novel practice would not be an anomaly in the firm. The firm had never had a practice like Daugerdas was offering. His rationale for the special compensation was that the firm's marginal cost for the transactions was fairly low, since the shelters required a relatively small number of lawyers. The firm therefore would recover its costs from fees relatively quickly. Anything above that was a premium, Daugerdas argued, of which he should be able to claim a significant share. This might create some challenges to his integration into the firm, but Jenkens had grown by being active in the lateral market. This often required making tailored agreements with individual rainmakers, which always creates the risk that a lawyer will act as a solo practitioner. To date, however, the firm had been able to strike the balance successfully.

Finally, the firm knew that Daugerdas would be running a new office in Chicago, rather than coming into an office in which Jenkens lawyers already worked. In the modern age, his location in Chicago, away from the firm's core in Dallas, would present no obstacle to effectively practicing as a member of the firm. It would, however, mean that Daugerdas would not be subject to the kind of informal norms that people can impose in regular face-to-face relationships with one another. Daugerdas effectively would be running his own practice just as he had before; only the name of the law firm on the door would be different. This would reinforce his sense that he could operate more or less in unfettered fashion.

The Jenkens culture, of course, encouraged branch offices to act independently, which many saw as a strength of the firm. Some observers expressed concern that the firm was 
devoting insufficient effort to integrating the different practice groups and offices that it was rapidly acquiring. Every acquisition of a lawyer, a practice group, or a firm makes sustaining a common organizational culture more difficult. Successful firms address this risk by devoting resources to the task of socializing newcomers into the values and norms of the firm. The existence of such a common culture can be crucial in allowing a firm to follow a coherent business strategy, promote non-financial goals, and weather difficult market conditions.

At the same time, Jenkens had flourished by promoting branch office autonomy. Many saw it as a strength of the firm. Allowing Daugerdas to run the Chicago office required simply that the firm continue its policy, without the need to make special arrangements. This was the path of least resistance, and less of a potential disruption than encouraging a discussion of whether the firm should do more than require a second signature on tax shelter opinions. Branch office autonomy thus offered a familiar script that could allow the firm to avoid considering whether integrating Daugerdas into the firm posed a special challenge.

\section{Managing the Risks}

Once the firm identified the risks that Daugerdas would pose, the issue was how well the firm could minimize them. Daugerdas estimated that he could generate around $\$ 6$ million a year in revenues from his tax shelter practice. While this was a healthy figure, it didn't suggest a level of activity and profits that should trigger particularly close scrutiny or require especially tight supervision. The firm had in place a system for monitoring the potential risks of all its practice areas. Daugerdas' practice wouldn't involve such a different level of risk that the firm needed to depart much from those procedures. A lawyer in Texas signing off on the opinions would be sufficient to protect the firm. In other words, the standard script would apply. 
The problem was that having another lawyer review the tax shelter opinions was a seriously limited monitoring system. Some tax lawyers had suggested to management that effective oversight required someone familiar with the highly technical subject of tax shelters in general, and with the specific transactions for which opinions were being issued. No one in the firm had worked on tax shelters. Michael Cook would be presented with opinions that were based on representations about transactions in which clients were intending to engage and their motivation for doing so. He would not be in a position, however, to determine if those representations accurately described the taxpayer's genuine intentions. This would be crucial in assessing whether tax losses from the transaction were likely to be upheld, since clients had to be motivated by a legitimate business purpose or reasonable hope of economic gain.

Futhermore, Cook would be in a rather difficult spot. The firm already had implicitly endorsed Daugerdas' shelter by deciding to hire him after a debate on its propriety. Daugerdas thus likely assumed that he would routinely receive approval for transactions that followed this template. In addition, Cook effectively stood between his partners and an additional $\$ 6$ million to divide among them (including himself, of course). Placing this burden on a single lawyer can subtly affect his judgment, no matter how personally upstanding the lawyer is.

The deficiencies of the review process were magnified exponentially because the firm seriously misjudged the risks that Daugerdas would pose. First, Daugerdas had vastly underestimated the revenues that he would generate. He had projected revenues of about $\$ 6$ million a year. In 1999 his practice produced about \$28 million in income, or almost five times the amount that the firm anticipated. This figure was more than $13 \%$ of the firm's total revenues. In 2000, he generated almost $\$ 91$ million in revenues, or almost a third of Jenkens' revenues. 
Daugerdas presumably had no motive when he approached Jenkens to underestimate the fees he expected to earn. What neither he nor the firm foresaw was that competitive pressures were leading accounting firms to gear up in a major way at the beginning of 1999 to launch unprecedented aggressive marketing campaigns to sell tax shelters over the next couple of years. The result was an explosion of shelter activity that generated hundreds of millions of dollars a year. The activity at Jenkens was so frenetic, for instance, that the firm periodically had to send legions of lawyers up to Chicago just to fill in investor information on documents connected with the shelters that Daugerdas was designing and selling.

Had Daugerdas come to Jenkens with a projection of this much annual revenue, it's likely that the firm would have been far more cautious about moving forward - if it did so at all. Fees of this magnitude were unprecedented in tax practice, and likely would have presented a red flag for most law firms. How could he be generating so much when top-tier firms were not? The nagging sense that Daugerdas was offering a deal that was too good to be true bothered several members of the firm even when he provided his $\$ 6$ million estimate. That sense of concern would be even deeper and broader if he had estimated that in two years he would be generating almost a third of the firm's revenues. No firm wants to be that dependent on a single lawyer. Aside from the obvious financial vulnerability this creates, it radically transforms the balance of power and the compensation schedule in the firm.

Furthermore, a lawyer who brings in that much in fees can subtly undermine the exercise of judgment in the firm. If his practice begins to shade into misconduct a firm has a strong incentive to look the other way, to rationalize his behavior, and to resist taking steps to rein him in or let him go. This was one reason why David Laney had set a goal that no client would 
constitute more than $4 \%$ of the firm's business when he became president of Jenkens. Daugerdas eventually would generate more than seven times that amount of the firm's revenues.

The unanticipated size of Daugerdas' earnings also seriously handicapped the firm's effort to provide meaningful oversight of the tax shelter work. With lawyers conscripted to plug information about individual investors into hundreds of tax shelter opinions, one tax partner in Texas could not be expected to keep up with, much less closely scrutinize, all the work that Daugerdas was producing. Furthermore, even he had, there would have been powerful pressures to sign off on opinions generating such a huge stream of revenue. Once the stream began to flow, the firm had even less incentive to strengthen oversight and every incentive to avoid confronting the question how a commodity practice could produce such outsized rewards.

The second way in which the firm underestimated the risks that Daugerdas posed is that it didn't give sufficient weight to the possibility that the IRS might do more than simply disallow benefits claimed from tax shelters. The agency also could take action against Daugerdas and any other Jenkens lawyers involved in tax shelter work. Tax law is one of the few fields of practice in which in which an agency is authorized to regulate and take disciplinary action against practitioners, which may include barring them from appearing before the IRS. Furthermore, particularly with respect to tax shelters, lawyers provide identifiable work product that can be the basis for such disciplinary action. The prospect of such action thus is a distinctive risk that should be taken into account

Third, the firm apparently never considered the possibility of criminal liability for Daugerdas' work. There was always a theoretical possibility of prosecution. The IRS had been quiescent for several years about tax shelter enforcement in general, however, and had rarely triggered criminal actions against shelter promoters or investors. In addition, many saw the 
economic substance and business purpose doctrines as sufficiently ambiguous that it would be difficult to establish criminal intent in connection with a transaction that produced a tax loss.

As a result, the risk that Jenkens anticipated was that an investor might sue the firm for malpractice because the IRS disallowed a shelter and made the taxpayer liable for back taxes and penalties. The firm's understanding, however, was that no lawyer had ever been sued for giving a tax shelter opinion. (Fairbank \& Maxon 2007) The firm assumed that getting a second signature on the opinions would minimize this possibility, and obtained assurance from its carrier that its insurance was adequate to cover the risk if it materialized. Jenkens had absorbed a large number of lateral partners and practice groups over the years, and felt that it had gained experience in managing the risks that laterals posed. There was a script for handling these risks, which the firm could follow when it brought Daugerdas aboard. The problem, however, was that this script was inadequate to deal with the nature and magnitude of the risks that Daugerdas actually posed.

\section{Conclusion}

Jenkens \& Gilchrist is the story of a regional firm with national ambitions, which sought to use Paul Daugerdas to make the leap to premium billing without the need to provide customized high-end legal services. It was an aggressive firm that had grown rapidly by acquiring profitable laterals, and it believed that it had learned how to manage the risks associated with them. As long as there was some colorable legal support for Daugerdas' tax shelters, management saw the decision as involving a business judgment about whether the rewards were worth the risk. The firm concluded they were. A major surge in tax shelter activity boosted the firm's revenues by a staggering amount and seemed to vindicate that 
conclusion. That same surge, however, prompted an ambitious enforcement campaign by the government that dramatically raised the stakes and eventually brought the firm to its knees.

Jenkens' experience underscores the importance of conducting fine-grained analyses of the competitive pressures that beset a law firm and the organizational dynamics that shape its response. A better understanding of law firm culture would be especially valuable in conducting such analysis. Jenkens had lawyers who were responsible for ethics issues, who conducted considerable training within the firm. It had a deliberative process in place that allowed opponents of hiring Paul Daugerdas to make their case at the highest level of the firm. It had a policy of requiring a second opinion on firm legal opinions that it adapted for use in monitoring Daugerdas' tax shelters. These measures reflect the laudable trend in recent years for law firms to establish a more sophisticated "ethical infrastructure." (Chambliss \& Wilkins)

The Jenkens story, however, illustrates the ways in which organizational culture shapes the deliberations that occur within such an infrastructure. Culture influences whether decisions are framed as involving business risks or ethical choices, the assessment of the nature and magnitude of risks, and the determination of how well the firm can manage these risks. All these judgments affect the ability of a firm to recognize when it is necessary to depart from reliance on standard scripts. A further layer of complication, of course, is the extent to which subcultures exist within the firm and their influence on the deliberative process.

The recent economic downturn may well dislodge law firm reliance on a single model to provide legal services. Instead, there are likely to be multiple models that firms pursue, which means that law firm trajectories will be even more diverse than they are now. Those of us who study the legal profession therefore need to attend closely to how law firm culture is created, transmitted, interpreted, contested, and revised. This analysis can help us develop a conceptual 
middle ground between the broad claim that business pressures now exert significant influence

on law firm behavior, and the recognition that every unhappy law firm is unhappy in its own way.

\section{References}

The American Lawyer (1999, July). Merger Mania: The Texas Shuffle, p. 74.

The American Lawyer (2007, July). Lessons of the AmLaw 100, p. 127.

Beck, Susan. (2007, November). The Transformers, The American Lawyer, pp. 94-99, 110

Braverman, Paul. (2003, December). Helter Shelter, The American Lawyer, p. 65.

Lynnley Browning. (2004, November 8). Lawsuit Over Tax Shelters May Derail A Settlement, N.Y. Times, p. C2

Chambliss, Elizabeth \& Wilkins, David B. (2002). The Emerging Role of Ethics Advisors, General Counsel, and other Compliance Specialists in Large Law Firms, Ariz. L. Rev. 44: 559.

Daly, Mary C. \& Silver, Carole. (2007). Flattening the World of Legal Services? The Ethical and Liability Minefields of Offshoring Legal and Law-Related Services, Geo. J. Internatl. L. 38: 401- 447.

Darley, John. (2005). The Cognitive and Social Psychology of Contagious Organizational Corruption. Brooklyn L. Rev. 70:1177-1194.

Darley, John M., Messick, David M., \& Tyler, Tom R. (1997). Social Influences on Ethical Behavior in Organizations. Mahwah, N.J.: Lawrence Erlbaum.

Fairbank, Katie \& Maxon, Terry. (2007 April 1). How Jenkens \& Gilchrist Lost Its Way, Dallas Morning News, p. 1A.

Galanter, Marc, \& Henderson, William. (2008). The Elastic Tournament: A Second

Transformation of the Big Law Firm, Stanford Law Review 60: 1867-1929

Galanter, Marc \& Palay, Thomas. (1991). Tournament of Lawyers: The Transformation of the

Big Law Firm. Chicago and London: University of Chicago Press.

Gioia, Dennis. (1992). Pinto Fires and Personal Ethics: A Script Analysis of Missed Opportunities, J. Business Ethics 11:379-389.

Granberry, Michael. (2000, May 7). Directions Change, But the Highway Man is Driven to Succeed, Dallas Morning News, p. 1E.

Gregory v. Helvering. (1935). 293 U.S. 465

Hansen, Susan. (1995, September). The Young and the Restless, The American Lawyer, pp. 6773.

Henning, Joel. (2007). Strategic Planning, in Hildebrandt Handbook of Law Firm Management (pp. 1-1-1-26). St. Paul: Thomson/West.

Internal Revenue Service Press Release. (2007, March 27). Jenkens \& Gilchrist Admits It Is Subject to $\$ 76$ Million IRS Penalty.

Jenkens \& Gilchrist. (2007, March 29). Statement of Jenkens \& Gilchrist. 
Klein, Chris. (1998, January 12). A Texas Firm Leads Nation in Growth, National Law Journal, pp. A1, A11.

Koppel, Nathan. (2007a, May 17). Fatal Vision: How a Bid to Boost Profits Led to a Law Firm's Demise, Wall Street Journal, p. A1.

Koppel, Nathan. (2007, July 6). Partner is No Longer A Tenured Position, Wall Street Journal, p B1.

Kunda, Z. (1990). The Case for Motivated Reasoning. Psychological Bulletin, 108(3), 480-498. Sol M. Linowitz. (1994). The Betrayed Profession: Lawyering at the End of the Twentieth Century. Baltimore and London: Johns Hopkins University Press.

Langevoort, Donald. (2002). The Organizational Psychology of Hyper-Competition: Corporate Irresponsibility and the Lessons of Enron, Geo. Wash. L. Rev. 70: 968-975. Maister, David. (1993). Managing the Professional Services Firm. New York: Free Press. McCollam, Douglas. (2003, September 15). True Confession? Daily Deal/The Deal. Messick, David M., and Tenbrunsel, Ann E. (eds.) (1996), Codes of Conduct: Behavioral Research into Business Ethics. New York: Russell Sage Foundation.

Nelson, Robert. (1988). Partners with Power. Berkeley and London: University of California Press.

Regan, Milton C., Jr., (2004). Eat What You Kill: The Fall of a Wall Street Lawyer. Ann Arbor: University of Michigan Press

Rostain, Tanina. 2006. Sheltering Lawyers: The Organized Bar and the Tax Shelter Industry, Yale J. on Reg. 23: 77-120.

Susskind, Richard, (2009). Rethinking the Nature of Legal Services. Oxford: Oxford University Press.

Tenbrunsel, Ann E. \& Messick, David M. (2004). Ethical Fading: The Role of Self-Deception in Unethical Behavior, Social Justice Research 17:223-236.

Tenbrunsel, Ann E. \& Messick, David M. (1999). Sanctioning Systems, Decision Frames, and Cooperation. Admin. Sci. Q. 44:684-707.

Triedman, Julie. (2007, May 1). Top Design, The American Lawyer, pp. 135-139. United States Department of Justice, United States Attorney for the Southern District of New York, (2009, June 9). Indictment, United States of America v. Paul M. Daugerdas, et al., United States Department of Justice, United States Attorney for the Southern District of New York, (2007, March 26) Letter Re: Jenkens \& Gilchrist. 